\title{
Health and nutrition in public and private schools in the city of Recife
}

Myrtis de Assunção Bezerra 1

Eduardo Freese de Carvalho 2

Juliana Souza Oliveira 3

Vanessa Sá Leal 4

\footnotetext{
1,2 Centro de Pesquisas Aggeu Magalhães. Fundação Oswaldo Cruz. Av Prof. Moraes Rego, s.n. Campus UFPE. Cidade Universitária. Recife, PE, Brasil. CEP: 50.740-465. E-mail: myrtis_nut@yahoo.com.br

3,4 Universidade Federal de Pernambuco. Recife, PE, Brasil.
}

\begin{abstract}
Objectives: to analyze the implementation of initiatives and environments promoting healthy feeding as well as the practice of physical activity in public and private schools in Recife.

Methods: the schools selected in the City of Recife $(n=39)$ are part of the sample in the Study of Cardiovascular Risks in Adolescents (ERICA). The degree of implementation was estimated by means of interviews with the school manager emphasizing the following components: community participation, presence of healthy environments, partnership with the health segment, monitoring of nutritional status and nutrition policies. The variables selected were assigned points whose sum rated them as satisfactory implementation, poor implementation and critical implementation.

Results: the promotion of healthy eating as well as the practice of physical activity was satisfactorily implemented in 13.8\% of public schools. However, no private schools obtained such rating. Public schools, when compared to private schools, showed themselves to be more structured, concerning the policies and environments promoting healthy eating and school community participation, however, they showed greater fragility regarding the promotion of physical activity practice and nutritional status monitoring. A few schools had satisfactory implementation in the partnership with the health segment.

Conclusions: public and private schools have presented barriers which compromise the full implementation of initiatives and environments promoting healthy eating and physical activity practice.
\end{abstract}

Key words Health promotion, School feeding, Physical activity, Adolescent, School health 


\section{Introduction}

Chronic non-communicable diseases (CNCD), particularly cerebrovascular accident, heart attack, diabetes and arterial hypertension, constitute health problems with greater magnitude in the global scope. For the period between 2010 and 2020, the World Health Organization (WHO) projections indicates an increase of $15 \%$ in mortality caused by this group of diseases. ${ }^{1}$ In Brazil, CNCD are responsible for $72.7 \%$ of the deaths, ${ }^{2}$ emphasizing that overweight and obesity are the main contributors for the charge of chronic diseases in the population. ${ }^{3}$

Researches show that part of these health problems has its origins in the childhood or adolescence. 4,5 In the perspective defined by life course epidemiology, early preventive strategies are emphasized so that they guarantee, for example, appropriated nutrition during the phases and actions which build favorable environments to health and also support healthy choices. 1,5,6

From this framework, besides primary prevention, health promotion has been configured as theoretical and practical alternative, necessary to face these complex factors which constitute the current epidemiological framework of the CNCDs.7,8 To consider, beyond the biological aspects, the environmental, cultural and social contexts promotes a broader approach, more coherent with the health promotion. $8-10$

For gathering together the majority of adolescents in a country, school environment represents a privileged space for developing these actions. 11,12 The promotion of health in school constitutes a world-class initiative which makes possible a greater interaction between teachers and health professionals for inter-sectorial and collaborative actions which deal with the situations of vulnerability of adolescent's health, including parental support and cooperation and stimulating policies in this community. $13-14$

In Brazil, such objectives are endorsed in the National Policy of Health Promotion and the Health Program at School (PSE - Programa de Saúde da Escola), which has intersecto-riality as one of its main guidelines. 15 These initiatives can be evaluated based on three interrelated components:1) integral health education, 2) creation and maintenance of physical and psychosocial healthy environments, 3 ) and the offer of health services, healthy eating and active life. 14

The presence of these components in schools may promote healthy eating behaviors and the practice of physical activity, which are fundamental measures for a healthy life and for the prevention of chronic non-communicable diseases in adult life. $13,16,17$

Consideringscarce the information on state of implementation of health promoting measures in schools in Recife city, and considering obesity, sedentary behavior and adoption of inappropriate eating habits as some of the main factors of morbidity in adolescents, the present study aims to evaluate the implementation of initiatives and health promoting environments, focused in healthy eating and the practice of physical activity aimed to adolescents in public and private schools in Recife.

\section{Methods}

This sectional study is part of a nationwide multicentric research, "Study of Cardiovascular Risk in Adolescents" (ERICA- Estudo de Riscos Cardiovasculares em Adolescentes). ERICA had as objective to estimate the prevalence of cardiovascular risk factors and metabolic syndrome in adolescents (12 to 17 years old) attending private and public schools from 273 municipalities with over 100 thousand inhabitants in Brazil.

Data related to the municipality of Recife (PE) were selected for the present article. Data collect occurred in the period between July and November, 2015. Criteria of eligibility include public and private schools from urban areas, from elementary school (last years) and/or high school which contributed with ERICA.

The sampling process tried to preserve the distribution of schools for administrative dependence, (public or private). In the sample, inside each geographical stratum, the method of systematic selection PPT (Size proportional probability) (PPTProbabilidade Proporcional ao Tamanho) was used, with previous assortment of schools from the selection registry by geographical stratum, situation and administrative dependence. Thus, 39 representative schools were selected for adolescent students from Recife municipality. The manuscript in which are described more details of the schools sampling is available in the Vasconcelos et al. ${ }^{18}$ article.

A theoretical operational model was elaborated based on the instruments proposed by Silva et al. 10 and by "Cuestionario The Health Behaviour in School-aged Children HBSC". ${ }^{19}$ This model oriented on the choice and adaptation of the variables. For each component and/or subcomponent the necessary structure (human and material resources) were specified, as well as the adequate process (actions to be executed), aiming short and medium term results 
which would lead, in long term, to the reduction of obesity and its cardiovascular complications (Figure1). The adapted version of the questionnaire was applied to the managers by means of interviews in each chosen school.

The questionnaire composed by opened and closed questions was divided in five components: 1) participation of the school community (parents, teachers and students) in the school activities; 2) presence of healthy environments; 3) fellowship with the health sector; 4) monitoring of the nutritional state and 5) nutrition policy of the school. In addition of these components, it was also evaluated manager's perception regarding the main problems of the districts and the visible barriers to implementation of health promotion in the school.

In order to verify the level of implementation of health promotion in the schools, a score system was used. Each item received a positive score $(1,0)$ when had this item accomplished, or null $(0,0)$ when it didn't. For items with more than one answer option, the score were categorized according to the level of relevance of the action, and it may receive 0,1 or 2 score. To consider as positive the items referring to "average number of meetings with the school community), answers which were superior to the average found in the sampling were used. Missing data were considered null and scored as " 0 " in the analysis. In the end, the maximum sum of every items from each positively answered component was of 40 points, distributed in 24 variables with maximum score of 1,0 point each and 8 variables with maximum score of 2,0 each.

By means of a simple rule of three, from the maximum score of the components (40 points) and the score obtained by each school, the level of implementation of each component was calculated, being defined as satisfactory when presented $70-100 \%$ of the implemented initiatives, unsatisfactory when 50 $69.9 \%$ and critical $<50 \%$. The joint analysis of these components made possible to estimate the degree of suitability of the initiatives promoting health eating and the practice of physical activity in the schools. The data analysis was executed using STATA 14.0 statistic software.

This study was approved by the Committee of Ethics in Research from the Research Center Aggeu Magalhães/FIOCRUZ 31446314.6.1001.5190. All the participants signed the Consent Form.

\section{Figure 1}

Theoretical operational model of promotion of healthy eating and physical activity practice in the school context.

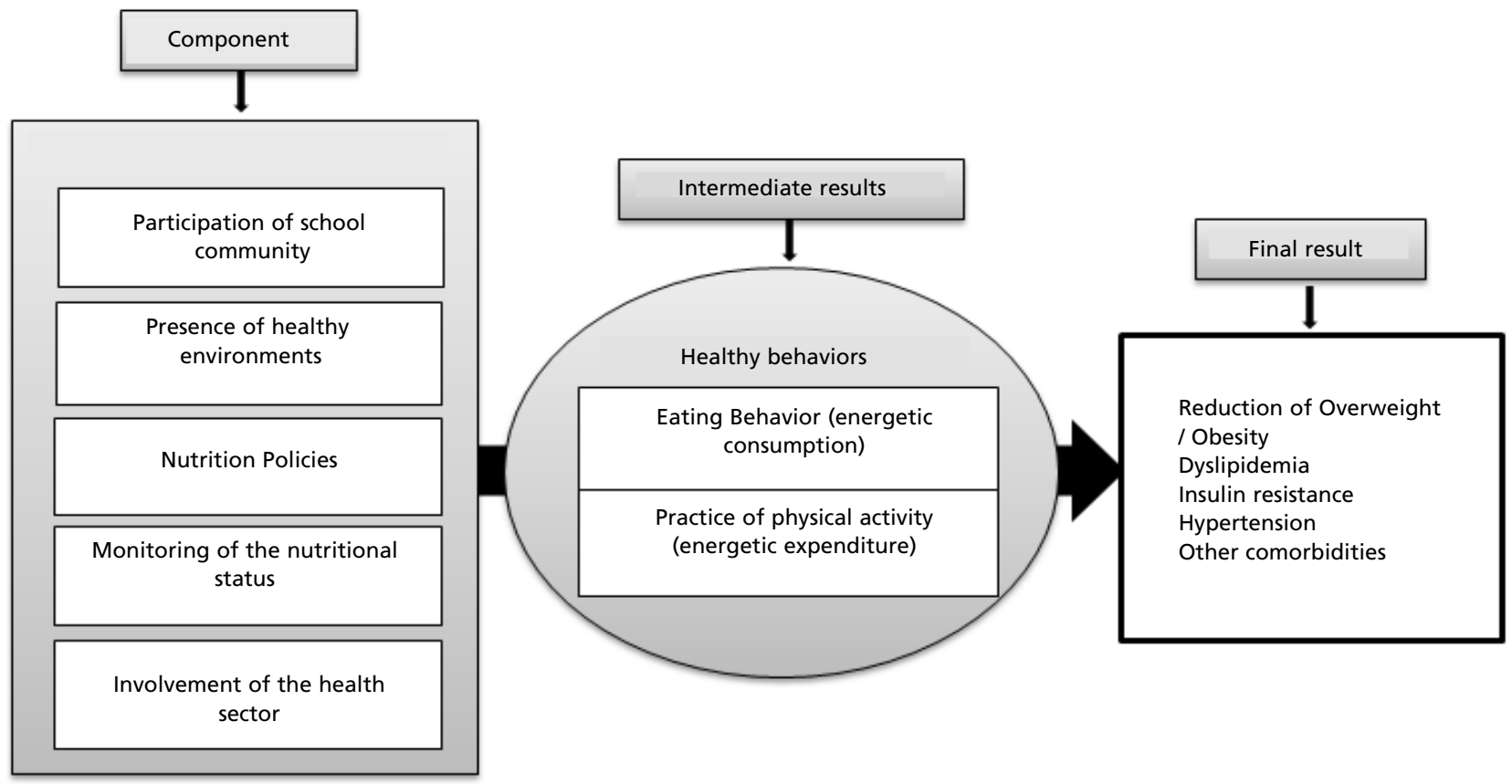




\section{Results}

From 39 selected schools, 38 participated in the study (29 public schools and 9 private schools). A manager from a private school $(3.8 \%)$ was not interviewed due to the finishing of the school activity in the unit. Among the interviewees, $76.3 \%(n=29)$ were principals, $13.2 \%(\mathrm{n}=5)$ coordinators and $10.5 \%(n=4)$ deputies.

The average of meetings held by public and private school networks, in order to approach the thematic of healthy eating with the parents was of $1.1 \pm 0.3$ and $1.3 \pm 0.5$ meetings/year, respectively. With the employees the average of meetings was of $5 \pm 1.2$, during the school year; in the private schools this average was of $0.8 \pm 0.3$. The suggestions made by the members of the school community were considered in the building of the Political Pedagogical Project (PPP) in $96.5 \%(n=28)$ of the public schools and $66.6 \%(n=6)$ of the private schools (Table 1).

Regarding the health topics, $24.1 \%$ of the public schools and $22.2 \%$ of the private ones did not include the healthy eating topic in the curriculum. The physical activity topic was inserted in $96.5 \%$ $(n=28)$ of the public schools and $100 \%(n=9)$ of the private ones. General health topics were found included in $100 \%$ of the approached schools (Table 1). Such discussions as prevention of sexual transmittable diseases $(96.5 \%$ vs $100 \%)$, prevention on the drug use $(93.1 \%$ vs $100 \%)$, prevention of early pregnancy $(89.6 \%$ vs $77.7 \%)$, neglected diseases (75.8\% vs $88.8 \%)$ and prevention of non-communicable chronic diseases $(75.5 \%$ vs $88.8 \%)$ were approached in the majority of private and public schools, respectively.

$66.7 \%$ of the private schools were evaluated with critical implementation for the component presence of health eating promoting environments (Table 2). Only $11.1 \%(\mathrm{n}=1)$ used the commercial space of health eating promotion (Table 1). Few schools had satisfactory implementation $(13.8 \%)$ regarding the presence of environments promoting health eating (Table 2) and a minority presented commercial snack bar inside $(\mathrm{n}=3 ; 10.3 \%)$. In contrast, "street vendors and local nearby commerce" were observed in 93.1\% $(\mathrm{n}=27)$ of the public schools(Table 1$)$.

$75.9 \%$ of the public schools had its physical environments to support physical activity considered inappropriate or in a bad state of conservation by the managers (Table 1). Only public schools presented critical degree regarding the implementation of this component in the school environment. (Table 2). The
Family Health Crews (ESF) from the Public Health System (SUS) did not hold periodical nor permanent visits in $96.5 \%(n=28)$ of the public schools. Besides, $58.6 \%$ of the public school network managers reported not knowing the Health in School Program. From the 29 public schools, only two reported to be participating PSE. In the private school network, $100 \%$ had fellowship with other institutions which promote healthy eating and/or health (Table 1).

The monitoring of weight and height was an item held in only $13.8 \%(n=4)$ and $22.2 \%(n=2)$ of public and private schools, respectively. In the same way, the orientation for the students in overweight/ obesity, developed by school, was reported by $17.2 \%$ $(n=5)$ of the public managers and $44 \%(n=4)$ of the private managers (Table 1). This was a component with critical implementation on $79.3 \%$ of the public schools and $77.8 \%$ in the private school network (Table 2).

The item "Increase the consumption of in natura food" was a nutrition policy found in $89.6 \%(\mathrm{n}=26)$ and in $44.4 \%(n=4)$ of the public and private schools, respectively. In the public school network, $96.5 \%$ $(\mathrm{n}=28)$ presented policies for not including food with abundant sugar, sodium and fat and/or with low nutritional value. In the private network, $44.4 \%$ preferred to apply this kind of policy (Table 1). This component was implemented satisfactorily in $37.9 \%$ of the public schools, whilst in public network, $88.9 \%$ of schools had critical rating (Table 2).

In the joint evaluation of the components, it was observed that four public schools $(13.8 \%)$ were classified as satisfactory, and, because of this, can be considered, according to the criteria followed in the present study, healthy eating and physical activity promoting schools. None of the private schools had satisfactory rating in this component (Figure 2).

Among the identified barriers for the implementation of health promotion, build fellowships with the health sector was the main difficulty referred in 20 public schools and 2 private schools. Also, inappropriate physical structure, resistance from the adolescents to adhere a healthy eating, the lack of training and incentive for the teachers regarding health topics, low participation from the parents in the school activities and the media influence in stimulate the consumption of low nutritional value food were highlighted points.

Beyond these barriers, $44.8 \%$ of the public school network and $22.2 \%$ from the private network realized as main problems from the districts where the schools were located, the "selling or use of drugs 
Frequency of schools according to the accomplishment of items for the development of community school participation, health environments, fellowship with the health sector, monitoring of nutritional state and nutrition policy. Recife (PE), Brazil, 2015.

\begin{tabular}{|c|c|c|c|c|c|c|c|c|}
\hline \multirow{4}{*}{ Components } & \multicolumn{8}{|c|}{ School Network } \\
\hline & \multicolumn{4}{|c|}{ Public } & \multicolumn{4}{|c|}{ Private } \\
\hline & \multicolumn{2}{|c|}{ Yes } & \multicolumn{2}{|c|}{ No } & \multicolumn{2}{|c|}{ Yes } & \multicolumn{2}{|c|}{ No } \\
\hline & $\mathrm{n}$ & $\%$ & $\mathrm{n}$ & $\%$ & $\mathrm{n}$ & $\%$ & $\mathrm{n}$ & $\%$ \\
\hline \multicolumn{9}{|l|}{ Participation of school community } \\
\hline \multicolumn{9}{|l|}{ Meetings/training (year) } \\
\hline $\begin{array}{l}\text { Meetings with parents to approach the healthy } \\
\text { eating topic above the averagea }\end{array}$ & 7 & 24.1 & 22 & 75.9 & 3 & 33.3 & 6 & 66.7 \\
\hline $\begin{array}{l}\text { Meetings with employees to approach the healthy } \\
\text { eating topic above the averageb }\end{array}$ & 12 & 41.3 & 17 & 58.7 & 0 & - & 9 & 100.0 \\
\hline Training for teachers about healthy food and health & 7 & 24.1 & 22 & 75.9 & 3 & 33.3 & 6 & 66.7 \\
\hline \multicolumn{9}{|l|}{ Building of PPP* } \\
\hline $\begin{array}{l}\text { Suggestions from meeting were considered in the } \\
\text { building of PPP* }\end{array}$ & 28 & 96.5 & 1 & 3.5 & 6 & 66.7 & 3 & 33.3 \\
\hline $\begin{array}{l}\text { Involvement of school community in the building of } \\
\text { PPP * }\end{array}$ & 26 & 89.7 & 3 & 10.3 & 6 & 66.7 & 3 & 33.3 \\
\hline $\begin{array}{l}\text { Involvement of teachers, principals, and coordinators } \\
\text { in the building of PPP* }\end{array}$ & 29 & 100.0 & 0 & - & 2 & 22.2 & 7 & 77.8 \\
\hline $\begin{array}{l}\text { Estimates of involved teachers in the building of PPP } \\
\text { above the averagec }\end{array}$ & 27 & 93.1 & 2 & 6.9 & 5 & 55.6 & 4 & 44.4 \\
\hline \multicolumn{9}{|l|}{ School Curriculum } \\
\hline $\begin{array}{l}\text { Inclusion of the healthy eating topic on the school } \\
\text { curriculum }\end{array}$ & 22 & 75.9 & 7 & 24.1 & 7 & 77.8 & 2 & 22.2 \\
\hline $\begin{array}{l}\text { Inclusion of physical education on the school } \\
\text { curriculum }\end{array}$ & 28 & 96.5 & 1 & 3.5 & 9 & 100.0 & 0 & - \\
\hline Inclusion of health topic in the school curriculum & 29 & 100.0 & 0 & - & 9 & 100.0 & 0 & - \\
\hline \multicolumn{9}{|l|}{ Healthy environments } \\
\hline \multicolumn{9}{|l|}{ Promoters of healthy eating } \\
\hline $\begin{array}{l}\text { Presence of refectory with capacity to meet the } \\
\text { demand of students during the meals }\end{array}$ & 13 & 44.8 & 16 & 55.2 & 5 & 55.6 & 4 & 44.4 \\
\hline $\begin{array}{l}\text { Presence of a specific space to the divulgation of } \\
\text { information on health and healthy eating }\end{array}$ & 24 & 82.8 & 5 & 17.2 & 6 & 66.7 & 3 & 33.3 \\
\hline $\begin{array}{l}\text { Involvement of the students in the building of these } \\
\text { spaces }\end{array}$ & 23 & 79.3 & 6 & 20.7 & 5 & 55.6 & 4 & 44.4 \\
\hline $\begin{array}{l}\text { Permanent destination of these specific spaces by } \\
\text { school }\end{array}$ & 10 & 34.5 & 19 & 65.5 & 3 & 33.3 & 2 & 66.7 \\
\hline $\begin{array}{l}\text { Presence of space for the execution of culinary } \\
\text { activities }\end{array}$ & 8 & 27.6 & 21 & 72.4 & 6 & 66.7 & 3 & 33.3 \\
\hline $\begin{array}{l}\text { Presence of school vegetable garden that promotes } \\
\text { healthy food }\end{array}$ & 4 & 13.8 & 25 & 86.2 & 3 & 33.3 & 6 & 66.7 \\
\hline $\begin{array}{l}\text { Presence of commercial snack bar which promotes } \\
\text { healthy eating }\end{array}$ & 1 & 3.4 & 28 & 96.6 & 1 & 11.1 & 8 & 88,9 \\
\hline Absence of snack bar in the school & 26 & 89.7 & 3 & 10.3 & 0 & - & 9 & 100.0 \\
\hline $\begin{array}{l}\text { Absence of street vendors and/or local trade nearby } \\
\text { school }\end{array}$ & 2 & 6.9 & 27 & 93.1 & 3 & 33.3 & 6 & 66.7 \\
\hline
\end{tabular}


Frequency of schools according to the accomplishment of items for the development of community school participation, health environments, fellowship with the health sector, monitoring of nutritional state and nutrition policy. Recife (PE), Brazil, 2015.

\begin{tabular}{|c|c|c|c|c|c|c|c|c|}
\hline \multirow{4}{*}{ Components } & \multicolumn{8}{|c|}{ School Network } \\
\hline & \multicolumn{4}{|c|}{ Public } & \multicolumn{4}{|c|}{ Private } \\
\hline & \multicolumn{2}{|c|}{ Yes } & \multicolumn{2}{|c|}{ No } & \multicolumn{2}{|c|}{ Yes } & \multicolumn{2}{|c|}{ No } \\
\hline & $\mathrm{n}$ & $\%$ & $\mathrm{n}$ & $\%$ & $\mathrm{n}$ & $\%$ & $\mathrm{n}$ & $\%$ \\
\hline \multicolumn{9}{|l|}{ Promoters of physical activity } \\
\hline $\begin{array}{l}\text { Presence of appropiate environments for physical } \\
\text { activity practive }\end{array}$ & 7 & 24.1 & 22 & 75.9 & 9 & 100.0 & 0 & - \\
\hline Practical course of physical routine during the week & 25 & 96,5 & 1 & 3.5 & 9 & 100.0 & 0 & - \\
\hline Extra physical activity during the week & 15 & 51.7 & 14 & 48.3 & 4 & 44.4 & 5 & 55.6 \\
\hline $\begin{array}{l}\text { Presence of refectory with structure to hold the } \\
\text { students demands during meals }\end{array}$ & 13 & 44.8 & 16 & 55.2 & 5 & 55.6 & 4 & 44.4 \\
\hline $\begin{array}{l}\text { Presence of a specific space to the divulgation of } \\
\text { information on health and healthy eating }\end{array}$ & 24 & 82.8 & 5 & 17.2 & 6 & 66.7 & 3 & 33.3 \\
\hline $\begin{array}{l}\text { Involvement of the students in the building of these } \\
\text { spaces }\end{array}$ & 23 & 79.3 & 6 & 20.7 & 5 & 55.6 & 4 & 44.4 \\
\hline \multicolumn{9}{|l|}{ Partnerships with the health sector } \\
\hline $\begin{array}{l}\text { Participation/partnership of a health professional } \\
\text { (volunteer or not) or agreement with health post } \\
\text { or hospital }\end{array}$ & 16 & 55.2 & 13 & 44.8 & 8 & 88.9 & 1 & 11.1 \\
\hline Health actions( $\geq 2$ times/year) & 10 & 34.5 & 19 & 65.5 & 3 & 33.3 & 6 & 66.7 \\
\hline $\begin{array}{l}\text { Partnership with institutions which promote healthy } \\
\text { eating and/or health }\end{array}$ & 4 & 13.8 & 25 & 86.2 & & - & 9 & 100.0 \\
\hline $\begin{array}{l}\text { Periodic and Permanent visitis from Family heath } \\
\text { crew }\end{array}$ & 1 & 3.45 & 28 & 96.5 & 2 & 22.2 & 7 & 77.8 \\
\hline \multicolumn{9}{|l|}{ Monitoring of the nutritional state } \\
\hline $\begin{array}{l}\text { Monitoring of weight and height of students } \\
\text { developed by school }\end{array}$ & 6 & 20.7 & 23 & 79.3 & 3 & 33.3 & 6 & 66.7 \\
\hline Monitoring of weight and height in all students & 4 & 13.8 & 25 & 86.2 & 2 & 22.2 & 7 & 77.8 \\
\hline Orientation for obese and overweight students & 5 & 17.2 & 24 & 82.3 & 4 & 44.4 & 5 & 55.6 \\
\hline \multicolumn{9}{|l|}{ Nutrition Policies } \\
\hline To enhance the consumption of in natura food & 26 & 89.6 & 3 & 10.34 & 4 & 44.4 & 6 & 55.6 \\
\hline $\begin{array}{l}\text { To limit the consumption of sweets foods, french } \\
\text { fries and soft drinks among students }\end{array}$ & 21 & 72.4 & 8 & 27.6 & 3 & 33.3 & 6 & 66.7 \\
\hline $\begin{array}{l}\text { Which determine that in school events foods such as } \\
\text { fruits, whole grains should be included among } \\
\text { the foods offered }\end{array}$ & 20 & 68.9 & 9 & 31.1 & 4 & 44.4 & 5 & 55.6 \\
\hline $\begin{array}{l}\text { Which indicates that food offered in the school } \\
\text { shouldn't have sugar, salt or fat or low } \\
\text { nutritional value }\end{array}$ & 28 & 96.5 & 1 & 3.5 & 4 & 44,4 & 5 & 55.6 \\
\hline $\begin{array}{l}\text { To emphasize the degree of processing of such } \\
\text { snacks as biscuits, ice creams and soft drinks }\end{array}$ & 21 & 72.4 & 8 & 27.6 & 6 & 66.7 & 3 & 33.3 \\
\hline
\end{tabular}

a Average: 1,1 meetings/year in public schools; 1,3 meetings/year in private schools; b Average: 5 meetings/year in public schools; 0,8 meetings/year in private schools; c Average: 2,4 teachers in public schools, 1,6 teachers in private schools; *PPP= Political pedagogical Project 
Frequency of schools according to the degree of implementation of the components of the school community participation, healthy environments, partnership with the health sector, monitoring of the nutritional state and nutrition policy. Recife (PE), Brazil, 2015.

\begin{tabular}{|c|c|c|c|c|c|c|c|c|c|c|c|c|}
\hline \multirow{4}{*}{ Components } & & \multicolumn{11}{|c|}{ School Network } \\
\hline & \multicolumn{6}{|c|}{ Public } & \multicolumn{6}{|c|}{ Private } \\
\hline & \multicolumn{2}{|c|}{ Satisfactory } & \multicolumn{2}{|c|}{ Unsatisfactory } & \multicolumn{2}{|c|}{ Critical } & \multicolumn{2}{|c|}{ Satisfactory } & \multicolumn{2}{|c|}{ Unsatisfactory } & \multicolumn{2}{|c|}{ Critical } \\
\hline & $\mathrm{n}$ & $\%$ & $n$ & $\%$ & $\mathrm{n}$ & $\%$ & $n$ & $\%$ & $n$ & $\%$ & $\mathrm{n}$ & $\%$ \\
\hline Participation of school community & 12 & 41.4 & 14 & 48.3 & 3 & 10.3 & 2 & 22.2 & 6 & 66.7 & 1 & 11.1 \\
\hline \multicolumn{13}{|l|}{ Presence of healthy environments } \\
\hline Healthy eating & 4 & 13.8 & 14 & 48.3 & 11 & 37.9 & 1 & 11.1 & 2 & 22.2 & 6 & 66.7 \\
\hline Physical activity practice & 3 & 10.3 & 16 & 55.2 & 10 & 34.5 & 2 & 22.2 & 7 & 77.8 & 0 & - \\
\hline Partnership with the health sector & 6 & 20.7 & 6 & 20.7 & 17 & 58.6 & 1 & 11.1 & 5 & 55.6 & 3 & 33.3 \\
\hline Monitoring of the nutritional state & 2 & 6.9 & 4 & 13.8 & 23 & 79.3 & 2 & 22.2 & 0 & - & 7 & 77.8 \\
\hline Nutrition policies & 11 & 37.9 & 7 & 24.1 & 11 & 37.9 & 0 & - & 1 & 11.1 & 8 & 88.9 \\
\hline
\end{tabular}

\section{Figure 2}

Frequency of public and private schools according to the degree of implementation of initiatives and environments promoting healthy eating and practice of physical activity. Recife, PE, Brazil, 2015.

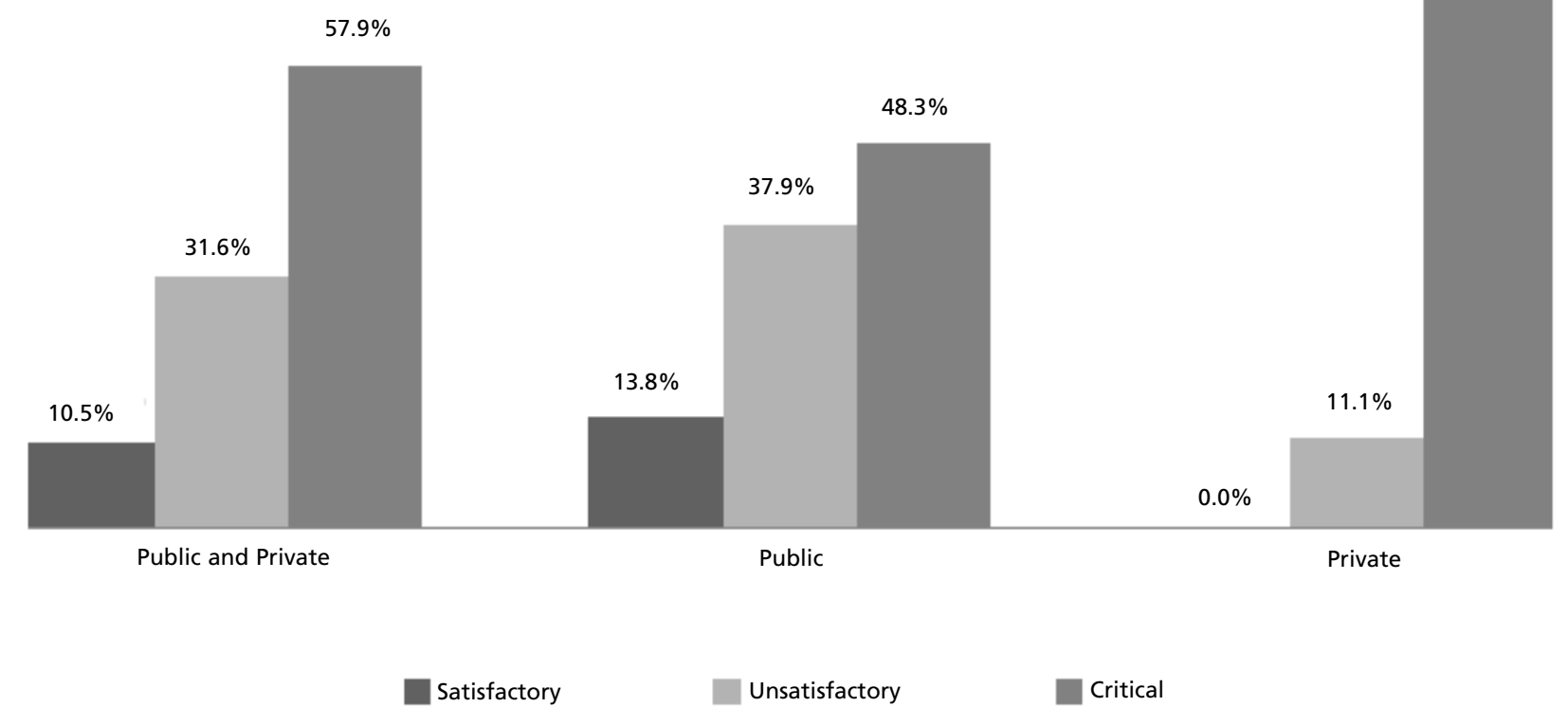


and alcohol consumption in public places". The "violence or vandalism" nearby school were problems related by $34.8 \%$ and $22.2 \%$ of the public and private schools, respectively. The remaining managers referred not being aware of these problems in the vicinity of the schools.

\section{Discussion}

The school can act as an enabling environment for the promotion of healthy eating behaviors and the practice of physical activity. 1,6,3,17 The high prevalence of schools which had unsatisfactory rating or explicit criticizing that the managers, the school community and the health sector have been facing barriers in the articulation and execution of these initiatives in the school environment.

The participation of the community is one of the requisites for classifying a school as a health promoter.14,19 In this study, the majority of managers referred that parents and employees were involved in the meetings and actions regarding health and healthy eating topics. However, the average number of meetings was considered low when compared to other studies. 10,20

The involvement of the school community represents a main role in social support to children and adolescents. This support is made available by friends, teachers and family, and can improve the school environment 13 as well as influence in the practice of physical activity and health eating behavior.21-25 Silva et al., 10 which also evaluated the participation of parents and teachers, indicate a low execution of these initiatives for the group of adolescents, which demonstrates the necessity of a higher guidance for this age group.

As it was established in the National Curricular Parameters, health topics were included in the curriculum of the majority of the analyzed schools, but it is not known if this inclusion operates in a transversal, contextualized and systematic way. 10 Despite of the concerning from the educators about these extracurricular and school activities, it is noted that the tasks developed in classroom are, in general, based in the particular understanding which each teacher possesses about what health is, with isolated, overlapping and discontinuous actions. 22,12 These teachers experience an array of difficulties in the elaboration and execution of health education. The discussion about the role of the teacher in this process, as well as his or her training, are necessary procedures in order to conduct the promotion of healthy behaviors in the school environment.
Internationally, agencies as $\mathrm{WHO}^{12}$ and $\mathrm{PAHO}^{14}$ recommend policies or rules of nutrition which determine the types of food available in schools, being aware that these are measures which stimulate healthy choices. $16,17,23,24$

The nutrition policies were found in the majority of public schools in Recife, however, in a few ones from private network. This framework is justified by the fact that in public schools, besides the offering of healthy food and the restriction of selling food considered non-healthy, there was an magnification of the actions in the teaching-learning context, which assume a pedagogical practice of educational action focused on the promotion of health. ${ }^{25}$ However, according to National Research of Student's Health (PeNSE 2012 - Pesquisa Nacional de Saúde do Escolar) appointment, 11 these policies are not well established in Brazilian private schools. This research reveals that the presence of snack bars and alternative spots of food selling was much higher in the private schools than in the public school network, and that these places offer a snacks of bad quality.

The contribution of school snacks can represent 25 to $50 \%$ of the total amount of nutrients ingested daily,26 and when they show low nutritional value and elevated caloric density, they can be considered as an important predictive factor for overweight and such comorbidities as hypertension, type 2 diabetes, and dyslipidemias in adolescence.8,13,27 In this context, the building of policies and environments which stimulate the choice of healthy food and restrict the selling of non-healthy food is a necessary measure for the promotion of health in schools.

The accessibility to places destined to sportive practice and school physical educationis recognized as an important facilitator for an active life. 22,28,29 Studies in this area have been verifying that interventions of physical activities in school environment reduce the body mass index (BMI), and is regular practice represents an important change in the nutritional state of this group. ${ }^{13,29}$ However, in about a half of the public schools from the municipality, the managers realized the structure of physical activity support as being inappropriate. In both of the school networks there were a reduced number of regular practical classes. Similar findings were described in the National Research of Student's Health. ${ }^{11}$

It is important to highlight that the school environment itself does not necessarily implies the participation of these students andthe adoption of more active behaviors. According to Santos et al.,22 the realization of barriers for the physical activity 
may include internal factors (individual characteristics and minor priority to physical activity) as well as external factors (influence of someone or of the family, inaccessibility, safety and cost).

The feeling of insecurity, due to the violence in the districts where the schools are located, was realized as one of the main problems by several managers in Recife municipality. This and other problems which the school community experience should be identified, debated and considered in the implementation of health promoting measures, once is very difficult to modify risk behaviors without changing social determinants that influence them. ${ }^{7,22,28,30}$

To monitor the nutritional state of the adolescents in school environment is considered a measure of prevention and of integral care regarding the aggravations related to eating and nutrition which focuses the reduction of overweight and obesity prevalence, as well as the CNCBs.4,10,11,27 In this study, few schools executed the monitoring of nutritional state of the adolescents. One of the main challenges for the health monitoring of the adolescents is to recognize that this group needs a greater healthcare and that the school and the health sector need to advance in the consolidation of an inter-sectorial model.

The lack of support of the health sector in public schools represent a problem of great magnitude which reflects the difficulty of the sector in dealing with the complexity of the health problems from the adolescents life stage. According to Reis et al., ${ }^{9}$ the Family Health Crews (ESF) which are responsible to perform periodic and permanent visits to the schools participating the Health in School Program, related that the main types of behaviors which make it difficult to approach this group were aggressiveness, refractoriness and transgression.

The PSE has intersectoriality as its main guidelines, which aims to articulate public schools and the basic health network to bring actions of prevention, promotion and healthcare to the public network students. 9,30 However, the results of this study demonstrate that over the half of managers of the state public school network related not knowing PSE, which indicates a low concreteness between the fellowships among health and education sectors in the municipality.

It is necessary to rethink the way of develop these actions in the public network schools, as well as to support these initiatives in the private schools, for the vulnerabilities to the health of adolescents. $9,14,30$ as well as the current epidemiological framework regarding the overweight in this group, $3,4,6$ demand measures of prevention to the aggravations associated to obesity and more integrated initiatives promoting health.

Besides the findings referred to previously, some limitations and its possible repercussions over the results should be discussed. First, the schools in this study represent the first stage of selection in a representative sample of the adolescent students from Recife. 18 Secondly, all the measures were obtained by means of a questionnaire and may present bias of answer. Despite of it, this is a field yet to be build, with few Brazilian studies, being necessary more researches to deepen the researched components, encompassing the evaluation, as well as the school community and the health crews involved.

In conclusion, the results of this study demonstrate that despite of the implementation still incipient and the existing barriers, the schools are, in a certain level, developing initiatives promoting healthy eating and/or practice of physical activity. In this respect, it is stressed that it is necessary to comprehend the reality of each school, to support the communication between the health and education sectors, to train managers, teachers, street vendors and snack bar owners, as well as stimulate the family involvement in the action destined to the adolescents. Probably, only from this process it will be possible to accomplish the necessary changes for the school environment to be a promoter of health attitudes and practices.

\section{References}

1. WHO (World Health Organization). Global status report on noncommunicable diseases 2014. Geneva. 2014 [acesso 4 dez 2015]. Disponível em: www.who.int/nmh/publications/ncd_report_full_en.pdf

2. Malta DC, Moura L, Prado RR, Escalante JC, Schmidt MI, Duncan BB. Mortalidade por doenças crônicas não transmissíveis no Brasil e suas regiões, 2000 a 2011. Epidemiol Serv Saúde. 2014; 23(4): 599-608.

3. Kearns K, Dee A, Fitzgerald AP, Doherty E, Perry IJ. Chronic disease burden associated with overweight and obesity in Ireland: the effects of a small BMI reduction at population level. BMC Public Health. 2014; 14: 143.

4. Bibiloni MM, Pons A, Tur JA. Prevalence of Overweight and Obesity in Adolescents: A Systematic Review. Hindawi Publishing Corporation. 2013; 1-14. 
5. Ben-Schlomo Y, Kuh D. A life course approach to chronic disease epidemiology: conceptual models, empirical challenges and interdisciplinary perspectives. Int J Epidemiol. 2002; 31 (2): 285-93

6. Duncan BB, Chor D, Aquino EML, Bensenor IM, Mill JG Schmidt MI, Lotufo PA, Vigo AB, SandhiM . Doenças crônicas não transmissíveis no Brasil: prioridade para enfrentamento e investigação. Rev Saúde Pública. 2012; 46 (Suppl. 1): 126-34

7. Fontbonne A, Cesse EÂP, Sousa IMC, Souza WV, Chaves VLV, Bezerra AFB, Carvalho EF. Risk factor control in hypertensive and diabetic subjects attended by the Family Health Strategy in the State of Pernambuco, Brazil: the SERVIDIAH study. Cad Saúde Pública. 2013; 29 (6): 1195 204.

8. Ribeiro AG, Cotta RMM, Ribeiro SMR. A promoção da saúde e a prevenção integrada dos fatores de risco para doenças cardiovasculares. Ciênc Saúde Coletiva. 2012; 17 (1): 7-17.

9. Reis DC, Almeida TAC, Coelho AB, Madeira AMF, Paulo IMA, Alves RH. Family health strategy: health care and vulnerabilities in the adolescence. Rev Espaço Saúde. 2015; 15 (1): 47-56.

10. Silva JRM, Schmitz BAS, Rodrigues MLCF, Gabriel CG. Promotion of healthy eating at schools in the Federal District of Brazil. Rev Nut. 2013; 26 (2): 145-58.

11. Brasil. Ministério da Saúde. Instituto Brasileiro de Geografia e Estatística. Pesquisa Nacional de Saúde do Escolar. RJ: 2012. [acesso 2 jun 16]. Disponível em: http://www.ibge.gov.br/home/estatistica/populacao/pense/2 012/comentarios.pdf

12. WHO (World Health Organization). What is a Health Promoting School? Geneva: WHO. 2006 [acesso 2 dez 2015]. Disponível em: http://www.who.int/school youth health/gshi/hps/en/print.html

13. Langford R, Bonell CP, Jones HE, Pouliou T, Murphy SM, Waters E, Komro KA, Gibbs LF, Magnus D, Campbell R. The world health organization's health promoting schools framework: a cochrane systematic review and metaanalysis. BMC Public Health. 2015; 15: 130

14. Ippolito-Shepherd J, Cerqueira MT, Ortega DP. Iniciativa regional escuelas promotoras de la salud en las Américas. Inter Union Health Promo Educ. 2005; 12 (3-4): 220-9.

15. Brasil. Ministério da Saúde. Secretaria de Vigilância em Saúde. Secretaria de Atenção à Saúde. Política Nacional de Promoção da Saúde. 3 ed. Brasília, DF; 2010. [acesso 14 ago 2015]. Disponível em: http://dab.saude.gov.br/ portaldab/

16. Silveira JA, Taddei JA, Guerra PH, Nobre MR Effectiveness of school-based nutrition education interventions to prevent and reduce excessive weight gain in children and adolescents: a systematic review. J Pediatr. 2011; 87: $382-92$.

Received on January 21, 2016

Final version presented on November 30, 2017

Approved on February 10, 2017
17. Zota D, Dalma A, Petralias A, Lykou A, Kastorini CM, Yannakoulia M, Karnaki P, Belogianni K, Veloudaki A, Riza E, Malik R, Linos A. Promotion of healthy nutrition among students participating in a school food aid program: a randomized trial. Int J Public Health. (2016) 61: 583-92.

18. Vasconcellos MTL, Silva PLN, Szklo M, Kuschnir MCC, Klein CH, Abreu GA, Barufaldi LA, Bloch KV. Desenho da amostra do Estudo do Risco cardiovascular em Adolescentes (ERICA). Cad Saúde Pública. 2015; 31 (5): 921-30.

19. Roberts C, Freeman J, Samdal O, Schnohr CW, de Looze ME, NicGabhainn S, Iannotti R, Rasmussen M. The Health Behaviour in School-aged Children (HBSC) study: methodological developments and current tensions. Int J Public Health. 2009; 54 (Suppl 2): 140-50.

20. Santos KF, Bógus CM. A percepção de educadores sobre a escola promotora de saúde: um estudo de caso. Ver Bras Crescimento Desenvolv Hum. 2007; 17 (3): 123-33.

21. Bauman A, Craig CL. The place of physical activity in the WHO Global Strategy on diet and physical activity. Int J Behav Nutr Phys Act. 2005; 2: 1-6.

22. Santos MS, Hino AAF, Reis R S, Rodriguez-Añez, CR. Prevalência de barreiras para a prática de atividade física em adolescentes. Rev Bras Epidemiol. 2010; 13 (1): 94104

23. Silva DCA, Frazão IS, Osório MM, Vasconcelos MGL. Percepção de adolescentes sobre a prática de alimentação saudável. Ciênc Saúde Coletiva. 2015; 20(11): 3299-308.

24. McKenna ML. Policy Options to Support Healthy Eating in Schools. Canadian Public Health Association. 2010; 101, (Suppl. 2): S14-7.

25. Peixinho AML. A trajetória do Programa Nacional de Alimentação Escolar no período de 2003-2010: relato do gestor nacional. Ciênc Saúde Coletiva. 2013; 18 (4): 90916.

26. Carvalho CA, Fonsêca PCA, Oliveira FP, Coelho AA, Arruda SPM. Consumo de energia e macronutrientes no lanche escolar de adolescentes de São Luís, Maranhão, Brasil. Cad Saúde Coletiva. 2014; 22 (2): 212-7.

27. Sichieri R, Souza RA. Estratégias para prevenção da obesidade em crianças e adolescentes. Cad Saúde Pública. 2008; 24 (Supl. 2): S209-S34.

28. Dias DF, Loch MR, Ronque ERV. Barreiras percebidas à prática de atividades físicas no lazer e fatores associados em adolescentes. Ciênc Saúde Coletiva. 2015; 20 (11): 3339-350.

29. Kirby J, Levin KA, Inchley J. Associations between the school environment and adolescent girls' physical activity. Health Education Research. 2012; 27 (1): 101-14.

30. Queiroz MVO, Lucena NBF, Brasil EGM, Gomes ILV. Cuidado ao adolescente na atenção primária: discurso dos profissionais sobre o enfoque da integralidade. Rev Rene. 2011; 12 (n. esp.): 1036-44. 